\title{
A priming role of local estrogen on exogenous estrogen-mediated synaptic plasticity and neuroprotection
}

\author{
Siriporn Chamniansawat ${ }^{1,3}$ and \\ Sukumal Chongthammakun ${ }^{2}$ \\ ${ }^{1}$ Faculty of Allied Health Sciences \\ Burapha University \\ Chonburi 20131, Thailand \\ ${ }^{2}$ Department of Anatomy and Center for Neuroscience \\ Faculty of Science \\ Mahidol University \\ Bangkok 10400, Thailand \\ ${ }^{3}$ Corresponding author: Tel, 66-38-393-497; \\ Fax, 66-38-393-497; E-mail, siripornc@ buu.ac.th \\ http://dx.doi.org/10.3858/emm.2012.44.6.046
}

Accepted 26 March 2012

Available Online 18 April 2012

Abbreviations: Arc, activity-regulated cytoskeleton associated protein; Bcl2, B cell lymphoma 2; DPN, estrogen receptor $\beta$ agonist; $\mathrm{E2}$, estrogen; ER, estrogen receptor; $\mathrm{GnRH}$, gonadotrophin releasing hormone; $\mathrm{H}_{2} \mathrm{O}_{2}$, hydrogen peroxide; OVX, ovarectomized; PI-3K, phosphoinositide kinase-3; PPT, estrogen receptor $\alpha$ agonist; PSD-95, postsynaptic density protein-95; Wort, wortmannin

\begin{abstract}
The localization of estrogen (E2) has been clearly shown in hippocampus, called local hippocampal E2. It enhanced neuronal synaptic plasticity and protected neuron form cerebral ischemia, similar to those effects of exogenous E2. However, the interactive function of hippocampal and exogenous E2 on synaptic plasticity activation and neuroprotection is still elusive. By using hippocampal H19-7 cells, we demonstrated the local hippocampal E2 that totally suppressed by aromatase inhibitor anastrozole. Anastrozole also suppressed estrogen receptor (ER) $\beta$, but not ER $\alpha$, expression. Specific agonist of ER $\alpha$ (PPT) and ER $\beta$ (DPN) restored ER $\beta$ expression in anastrozole-treated cells. In combinatorial treatment with anastrozole and phosphoinositide kinase-3 (PI-3K) signaling inhibitor wortmannin, PPT could not improve hippocampal ER $\beta$ expression. On the other hand, DPN induced basal ER $\beta$ translocalization into nucleus of anastrozole-treated cells.
\end{abstract}

\begin{abstract}
Exogenous E2 increased synaptic plasticity markers expression in H19-7 cells. However, exogenous E2 could not enhance synaptic plasticity in anastrozoletreated group. Exogenous E2 also increased cell viability and B-cell lymphoma 2 (Bcl2) expression in $\mathrm{H}_{2} \mathrm{O}_{2}$-treated cells. In combined treatment of anastrozole and $\mathrm{H}_{2} \mathrm{O}_{2}$, exogenous E2 failed to enhance cell viability and Bcl2 expression in hippocampal H19-7 cells. Our results provided the evidence of the priming role of local hippocampal E2 on exogenous E2-enhanced synaptic plasticity and viability of hippocampal neurons.
\end{abstract}

Keywords: estrogen receptor beta; estrogens; hippocampus; neuronal plasticity; neurons; neuroprotective agents

\section{Introduction}

E2 is mainly synthesized in the gonad, called gonadal or exogenous E2, and reaches its target organ via blood circulation. It has been reported to influence memory function (Henderson, 2010; Gorenstein et al., 2011) and neuroprotection (McCullough et al., 2003) through estrogen receptor (ER), which highly expressed in cerebral cortex and hippocampus (Henderson, 2010). In menopausal women, E2 replacement therapy relieved memory impairment (Gorenstein et al., 2011). Previous study demonstrated the decreasing of hippocampal dendritic spine in ovarectomized (OVX) rats that restored by an administration of exogenous E2 (Gould et al., 1990). During estrous cycle, the hippocampal spine density is varied in response to fluctuating level of E2 in female rats (Woolley and McEwen, 1992). Moreover, our previous studies demonstrated that a variety of synaptic marker proteins is up-regulated after exogenous E2 application (Chamniansawat and Chongthammakun, 2009; 2010), confirming the positive role of exogenous E2 on synaptic plasticity and memory consolidation. E2 also prevents neuronal death from ischemic brain injury (Dubal et al., 1999). It regulated neuronal viability through $\mathrm{Bcl} 2$ expression, but not other members of $\mathrm{Bcl} 2$ family (Dubal et al., 1999). 


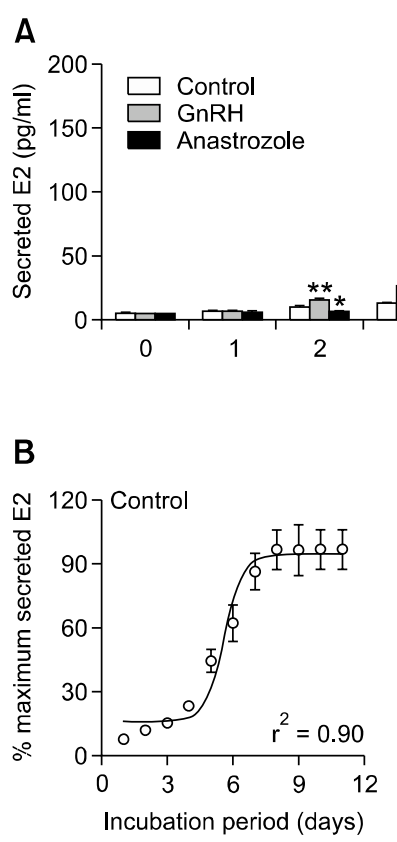

In addition to gonad, endogenous E2 production and secretion in hippocampus were well demonstrated (Prange-Kiel and Rune, 2006). The presence of all enzymes responsible for endogenous E2 biosynthesis and a sixfold higher E2 concentration in hippocampus than that in plasma (Hojo et al., 2004) strongly indicate the potential roles of local hippocampal E2 on hippocampal functions. Previous studies revealed that inhibition of the local E2 biosynthesis by aromatase inhibitor significantly reduced the density of hippocampal synapses and down-regulated synaptic proteins, including spinopholin and synaptophysin (Kretz et al., 2004; Mukai et al., 2010; Zhou et al., 2010). Local hippocampal E2 also regulated the expression of ER (Murata et al., 2003; Prange-Kiel et al., 2003; Oliveira et al., 2004). In addition to synaptic plasticity, the neuroprotective role of local hippocampal E2 had been demonstrated by using aromatase knockout mice (McCullough et al., 2003). Loss of endogenous or local E2 exhibited an increase in the severity of ischemic injury compared with the normal as well as OVX mice. These evidences indicated that the neuronal functions are mainly affected by local hippocampal E2. However, the decreased in synaptic plasticity was presented in OVX rats (Woolley and McEwen, 1992), which local hippocampal E2 should be intact. Therefore, hippocampal neuronal function is depended on both endogenous and exogenous E2. We hypothesized in the present study that the mechanism of exogenous E2 action is an endogenous E2-dependent manner. The aims of this study were to investigate the effects and mechanisms of endogenous E2 action on the

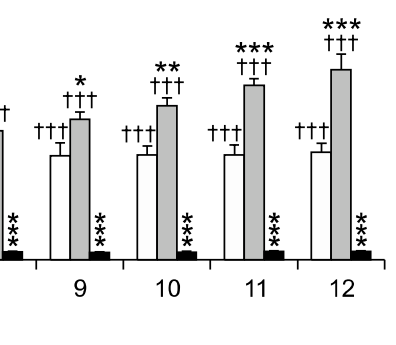

D

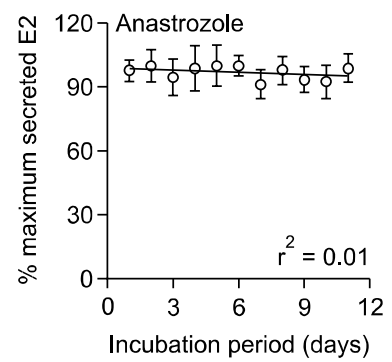

Figure 1. Secreted local E2 in culture media of hippocampal H19-7 neurons. Secreted E2 of control (open bars), GnRH-treated (gray bars) and anastrozole-treated (black bars) in H19-7 hippocampal cells (A). ${ }^{*} P<0.05,{ }^{* *} P<0.01,{ }^{* * *} P$ $<0.001$ vs day-matched control group, ${ }^{\dagger} P<0.05,{ }^{\dagger \dagger} P<0.01,{ }^{\dagger \dagger} P$ $<0.001$ vs corresponding day 0 group. Percent maximum secreted E2 of control (B), GnRH-treated (C) and anastrozole-treated (D) in H19-7 hippocampal cells. Dark line represented the best-fitted sigmoid line (non-liner regression) in $B$ and straight line (linear regression) in $\mathrm{C}$ and $\mathrm{D}(n=5)$.

modulation of synaptic plasticity and neuroprotection in hippocampal H19-7 cells.

\section{Results}

\section{Local E2 production in hippocampal H19-7 cells}

To determine the production and secretion of E2 in hippocampal H19-7 cells, we measured E2 concentration in culture media of untreated, gonadotrophin releasing hormone $(\mathrm{GnRH})$-treated or anastrozole-treated hippocampal $\mathrm{H} 19-7$ cells by using ELISA kit. At day 0, basal E2 levels of untreated, GnRH-treated, and anastrozole-treated cells were $5.46 \pm 0.51,5.11 \pm 0.25$, and $4.89 \pm$ $0.25 \mathrm{pg} / \mathrm{ml}$, respectively (Figure $1 \mathrm{~A}$ ). In untreated hippocampal H19-7 cells, secreted E2 significantly increased from days 5 through $12(37.52 \pm 4.58$ $\mathrm{pg} / \mathrm{ml}$ to $80.04 \pm 7.40 \mathrm{pg} / \mathrm{ml}$ ) (Figure $1 \mathrm{~A}$ ). Maximum secreted E2 level in untreated hippocampal H19-7 cells was comparable to those report in hippocampal slice cultures (Kretz et al., 2004). GnRH increased hippocampal E2 secretion from days 3 through 12 $(26.81 \pm 4.55$ to $148.72 \pm 12.47 \mathrm{pg} / \mathrm{ml}$ ) (Figure $1 \mathrm{~A})$. Moreover, when compared with the untreated group, $\mathrm{GnRH}$ significantly increased E2 levels from days 2 through 12 (Figure 1A). However, when the activity of aromatase was inhibited by anastrozole, the E2 levels were not changed throughout 12 days of experimental period.

The hippocampal E2 secretion profile of control, $\mathrm{GnRH}$-treated, and anastrozole-treated hippocampal H19-7 cells were demonstrated by the percent 
A

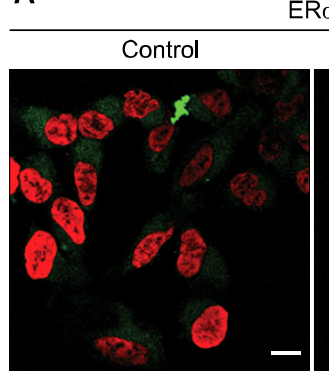

B

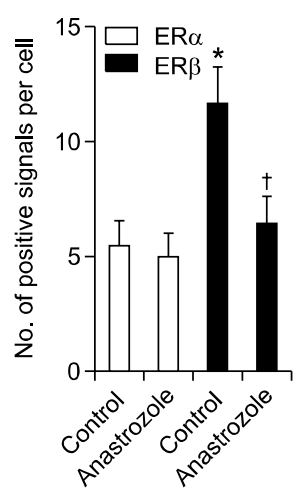

$\mathrm{ER} \alpha$
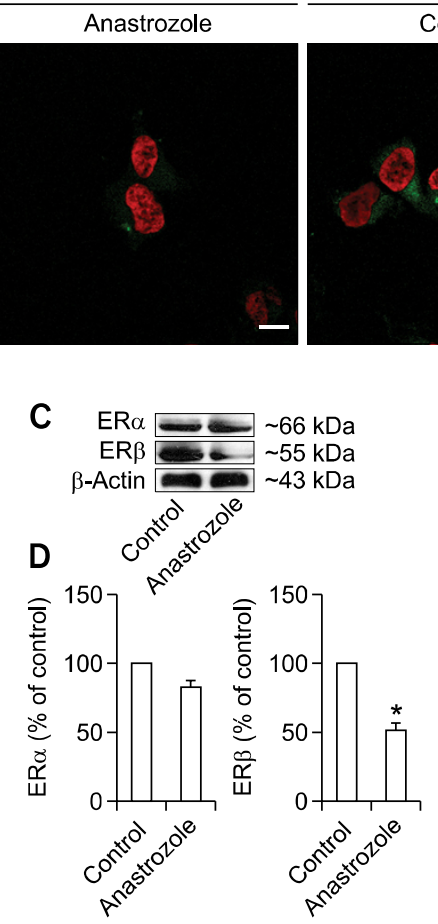

ER $\beta$

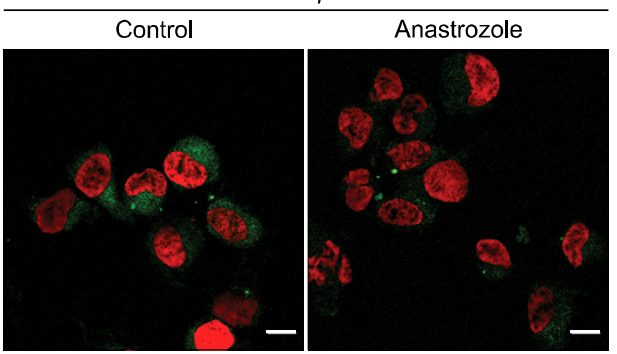

E

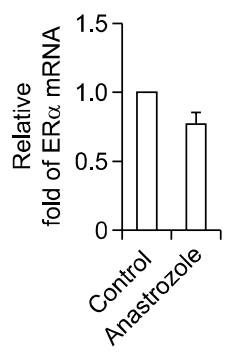

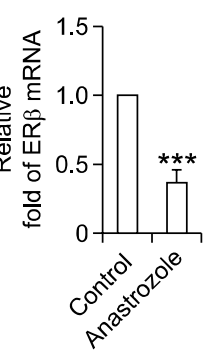

Figure 2. Endogenous H19-7 hippocacampal E2 regulates ER $\beta$ expression. Representative immunofluorescent images of $E R \alpha$ and ER $\beta$ expression of control, and anastrozole-treated H19-7 hippocampal cells (A). Red signal represented nuclear-staining and green signal represented ER $\alpha$ or ER $\beta$ (scale bars $=10 \mu \mathrm{m}$ ). The number of $E R \alpha$ or $E R \beta$ positive green signal was counted and presented (B). Quantitative immunoblot analysis of $E R \alpha$ and $E R \beta$ proteins expression in control and anastorzole-treated H19-7 hippocampal cells (C, D). Representative qRT-PCR of $E R \alpha$ and $E R \beta$ mRNA expression in H19-7 hippocampal neurons (E). $\beta$-actin was the housekeeping protein. ${ }^{*} P<0.05,{ }^{* * *} P<0.001$ vs control group, ${ }^{\dagger} P<0.05$ vs anastrozole-treated group $(n=5)$. maximum secreted E2-experimental period relationship. The data of control cells were best fitted with the non-liner regression equation that revealed the sigmoidal line $\left(r^{2}=0.90\right.$, Figure 1B). In the first three days, E2 levels slowly increased, while it rapidly increased from $4^{\text {th }}$ day and to the maximum level in $8^{\text {th }}$ day (Figure $1 \mathrm{~B}$ ). The half maximum E2 secretion was presented in $5^{\text {th }}$ day to $6^{\text {th }}$ day and the maximum E2 secretion with the plateau phase was showed in day 8 though 12 (Figure 1B). Therefore, we selected $8^{\text {th }}$ day as a suitable culture condition in next experiments for studied the effect of local E2 on hippocampal H19-7 neuron. GnRH changed the secretory profile form sigmoid function to linear function $\left(r^{2}=0.97\right.$, Figure $\left.1 \mathrm{C}\right)$. The E2 levels of $\mathrm{GnRH}$-treated group rapidly increased from day 1 through 12 (Figure 1C), whereas E2 levels of anastrozole-treated group showed relatively constant throughout 12 days of experimental period (Figure 1D).

\section{Local E2 regulates ER $\beta$ expression in hippocampal H19-7 cells}

It is well known that $E R$, including $E R \alpha$ and $E R \beta$, expression is upregulated by E2 (Murata et al., 2003; Oliveira et al., 2004). We therefore investigated the effects of the local E2 on ER expression by using the confocal immunocytochemistry, qRT-PCR, and Western blot techniques. To determine those effects, hippocampal H19-7 cells were cultured in either steroid-deprived media with or without anastrozole for 8 days. In control group, ER $\beta$ expression was significantly higher than ER $\alpha$ (Figures $2 A-2 D)$. In the presence of anastrozole, the level of ER $\beta$ expression was significantly decreased, whereas ER $\alpha$ expression was not changed (Figures 2A-2E). These results indicated that the local E2 up-regulated $E R \beta$, but not $E R \alpha$, expression in hippocampal H19-7 cells.

\section{Local E2-increased ER $\beta$ expression is a basal ER $\alpha-$ and ER $\beta$-dependent mechanism}

We further examined the underlying mechanism of local E2-induced ER $\beta$ expression by using qRT-PCR and Western blotting analysis. Hippocampal H19-7 cells exposed to anastrozole for 8 days had significantly lower ER $\beta$ expression than control group (Figures 3A-3C). The level of ER $\beta$ expression could be restored by administration of specific agonist of ER $\alpha$ (100 nM PTT) and ER $\beta$ (100 nM DPN) in day $7^{\text {th }}$ of experimental period. This result indicates that the local E2-induced ER $\beta$ expression is a basal $E R \alpha$ and $E R \beta$-dependent mechanisms. Wortmannin (200 nM Wort.), a specific PI-3K inhibitor, had no additive effect on anastrozolesuppressed ER $\beta$ expression (Figures 3A-3C). Wortmannin attenuated PPT-, but not DPN-, induced ER $\beta$ expression. Therefore, local hippocampal E2 

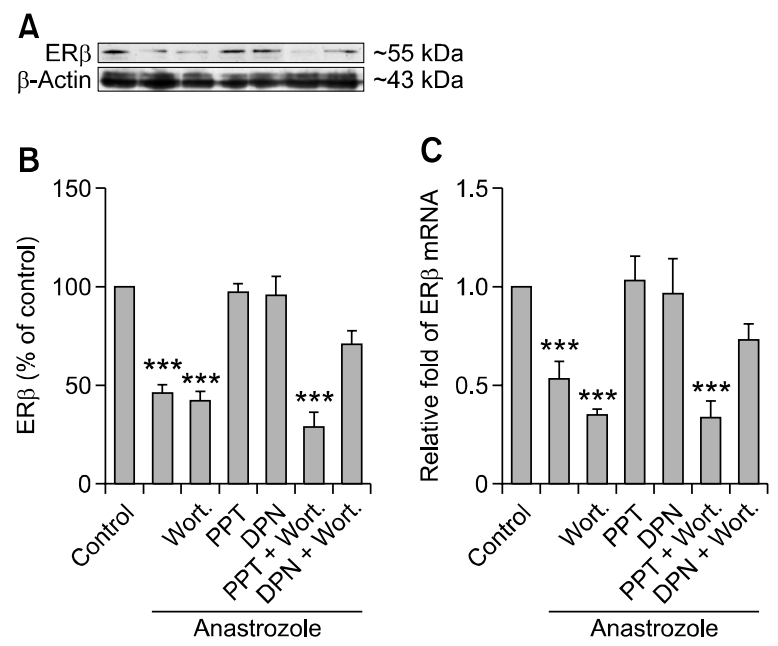

D

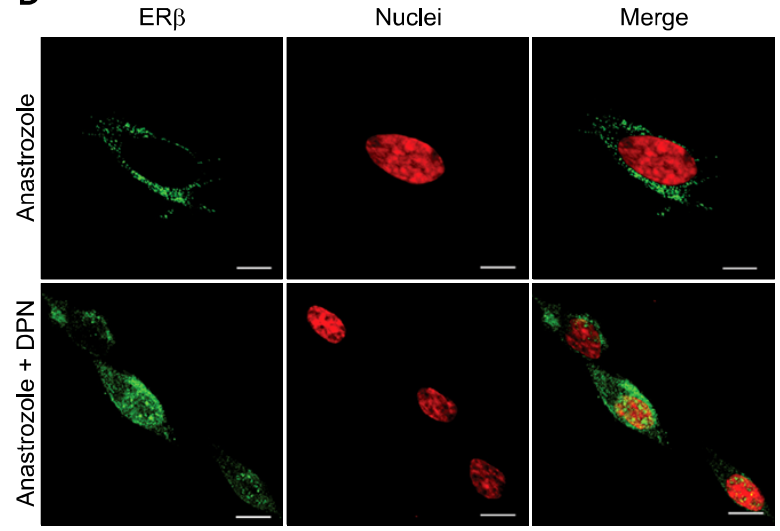

Figure 3. The mechanism of local hippocampal E2 regulated ER $\beta$ expression. The quantitative immunoblot analysis of ER $\beta$ in control and 8 days-anastrozole exposed neuron (A). 100 nM PPT, $100 \mathrm{nM}$ DPN, or $200 \mathrm{nM}$ Wortmannin (Wort.) was added to the culture media of anastrozole-treated neuron in 7-8 days prior to harvested cells. Representative densitometric analysis of ER $\beta$ expression in H19-7 cells (B). Representative immunofluorescent image of $\mathrm{ER} \beta$ (green signal) and nucleus (red signal) of anastrozole and anastrozole plus DPN-treated cells (C). Scale bar $=10$ uM. $\beta$-actin was the housekeeping protein. ${ }^{* * *} P$ $<0.001$ vs control group.

enhanced ER $\beta$ expression in basal ER $\alpha-\mathrm{PI}-3 \mathrm{~K}$ dependent mechanism.

We further examined the effect of local E2 on ER $\beta$ activation by determining the translocation of basal $\mathrm{ER} \beta$ in hippocampal $\mathrm{H} 19-7$ cells by using laser confocal microscopy (Figure 4D). In anastrozole treated group, the basal ER $\beta$ localized in cytoplasmic and membranous regions of hippocampal H19-7 cells. After DPN treatment, basal membranous and cytoplasmic ER $\beta$ decreased, but the nuclear ER $\beta$ increased. This findings suggest that the membranous and cytoplasmic ER $\beta$ translocalize into nucleus in ligand-dependent mechanism, indicating a characteristic of classical genomic action.
A

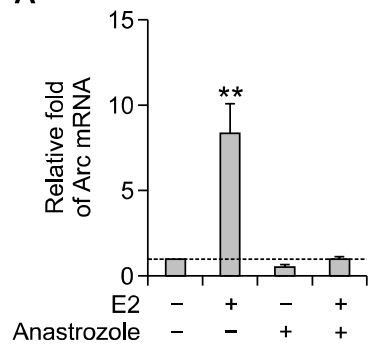

B
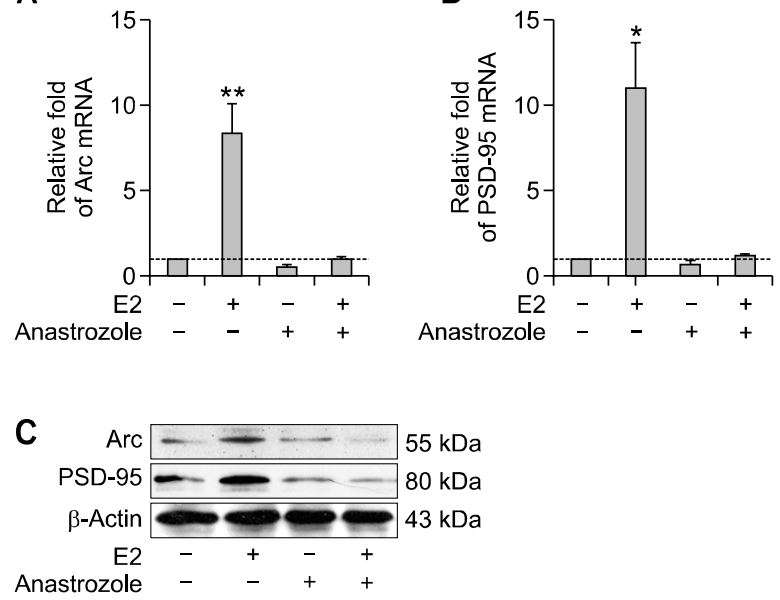

D

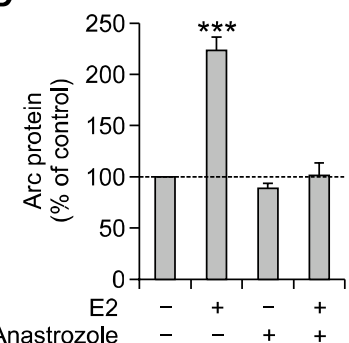

E

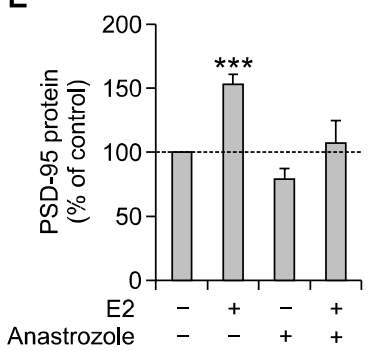

Figure 4. The effect of endogenous E2 on exogenous E2-induced H19-7 hippocampal synaptic plasticity. Representative quantitative qRT-PCR (A, B) and Western blotting analysis (C, D, E) of Arc and PSD-95 expression in H19-7 hippocampal neurons. Densitometric analysis of $\operatorname{Arc}(D)$ and PSD-95 (E) protein in H19-7 cells. GAPDH was the housekeeping mRNA in real-time PCR. $\beta$-actin was the housekeeping protein. ${ }^{*} P<0.05,{ }^{* \star} P$ $<0.01,{ }^{* * *} P<0.001$ vs control group $(n=5)$.

\section{Local E2 mediates exogenous E2-induced synaptic plasticity}

Although local hippocampal E2- and exogenous E2-enhanced hippocampal synaptic plasticity had been explained (Prange-Kiel and Rune, 2006), the role of the local E2 on exogenous E2-mediated synaptic plasticity is still unclear. By using synaptic plasticity markers, Arc and PSD-95, we observed the interactive effect of local and exogenous E2 on synaptic plasticity using QRT-PCR and Western blot analysis in hippocampal H19-7 cells. As shown in Figures $3 \mathrm{~A}$ and $3 \mathrm{~B}$, exogenous $\mathrm{E} 2$ treatment for 30 min and $6 \mathrm{~h}$ significantly increased Arc and PSD-95 mRNA expression, respectively. Anastrozole unaltered the basal Arc and PSD-95 mRNA expression. Interestingly, exogenous E2 could not enhance Arc and PSD-95 mRNA expression when hippocampal $\mathrm{H} 19-7$ cells were cultured in anastrozole-containing media (Figures $3 \mathrm{~A}$ and $3 \mathrm{~B}$ ).

Similar to those mRNA, administration of exogenous 
E2 (1 $\mathrm{h}$ and $48 \mathrm{~h}$ for Arc and PSD-95, respectively) also induced Arc and PSD-95 proteins expression (Figures 3C-3E). Anastrozole had no effect on basal Arc and PSD-95 proteins expression. Exogenous E2 failed to enhance Arc and PSD-95 protein expression in anastrozole-treated neurons (Figures $3 \mathrm{D}$ and $3 \mathrm{E}$ ). These findings indicated that hippocampal E2 was prerequisited for exogenous E2-enhanced hippocampal synaptic plasticity.

\section{Local E2 mediates neuroprotective effect of exogenous E2}

The neuroprotective effects of E2 have been well demonstrated. However, the involvement of local E2 on neuroprotective effect of exogenous E2 is still elusive. As demonstrated in Figure $5 \mathrm{~A}, 1 \mathrm{~h}$ of $200 \mu \mathrm{M}$ $\mathrm{H}_{2} \mathrm{O}_{2}$ exposure significantly decreased hippocampal H19-7 cell viability. $\mathrm{H}_{2} \mathrm{O}_{2}$-induced cell death was enhanced by anastrozole. Preincubation of the cells with exogenous $\mathrm{E} 2$ for $24 \mathrm{~h}$ prior to addition of $\mathrm{H}_{2} \mathrm{O}_{2}$ attenuated $\mathrm{H}_{2} \mathrm{O}_{2}$-induced cell death. However, therapeutic effect of exogenous $\mathrm{E} 2$ on $\mathrm{H}_{2} \mathrm{O}_{2}$-induced H19-7 cell death was absent when cells were exposed to anastrozole (Figure 5A).

We also observed the effect of local E2 and exogenous E2 on anti-apoptotic protein $\mathrm{Bcl} 2$, the specific target of E2 (Dubal et al., 1999). While $24 \mathrm{~h}$ of exogenous $\mathrm{E} 2$ preincubation significantly enhanced $\mathrm{Bcl} 2$ expression, $\mathrm{H}_{2} \mathrm{O}_{2}$ significantly suppressed its expression (Figures $5 \mathrm{~B}$ and $5 \mathrm{C}$ ). Additional effect of anastrozole on $\mathrm{H}_{2} \mathrm{O}_{2}$-supressed $\mathrm{Bcl} 2$ expression was demonstrated. Similar to those cell viability studies, exogenous $\mathrm{E} 2$ totally rescued $\mathrm{Bcl} 2$ expression in $\mathrm{H}_{2} \mathrm{O}_{2}$-treated $\mathrm{H} 19-7$ cells. Exogenous E2 could not restore $\mathrm{H}_{2} \mathrm{O}_{2}$-supressed $\mathrm{Bcl} 2$ expression in anastrozole treated neurons (Figures $5 \mathrm{~B}$ and $5 \mathrm{C}$ ). These findings suggest the prerequisite role of local hippocampal E2 on neuroprotective function of exogenous E2.

\section{Discussion}

De novo E2 production and secretion in hippocampus has been demonstrated in both primary hippocampal neurons (Prange-Kiel et al., 2003) and hippocampal slice cultures (Kretz et al., 2004). In the present study, we showed the production and secretion of local E2 in hippocampal H19-7 cells. Our findings demonstrate the sigmoidal secretory profile of H19-7 hippocampal E2. In first 3 days after seeding the secreted E2 levels relatively constant probably due to the preparation of intracellular machinery that responsible for production and secretion of E2, we named this period as "the

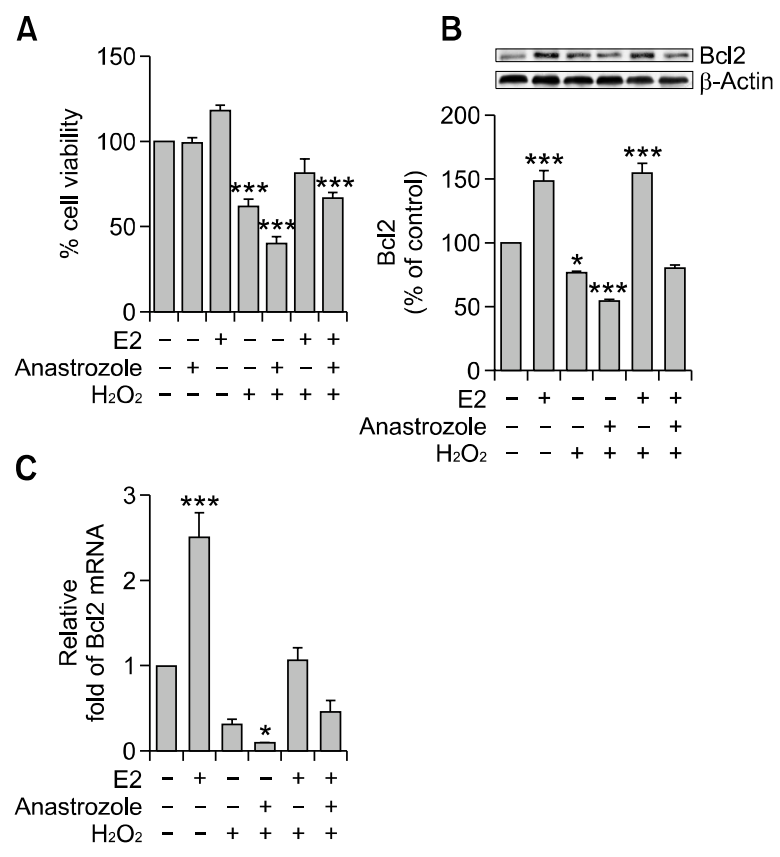

Figure 5. The effect of endogenous E2 on neuroprotective effect of exogenous E2. Representative cell viability data from MTT assay (A). Anti apoptotic Bcl2 expression in H19-7 hippocampal neurons (B and C). $\beta$-actin was the housekeeping protein. ${ }^{*} P<0.05$, ${ }^{* * *} P<0.001$ vs control group $(n=5)$.

preparation state". In days 4 to 7 , secreted E2 rapidly increased form $16.2 \%$ to $90.6 \%$ of maximum secreted E2; it was named "the active state". Finally, secreted $\mathrm{E} 2$ reached the maximum plateau state in days 8 to 12 . However, secreted $E_{2}$ levels were relatively unaltered when hippocampal $\mathrm{H} 19-7$ cells were incubated with anastrozole. This finding indicates that E2 production and secretion in hippocampal H19-7 cells required aromatase activity similar to those reported in primary hippocampal neurons (Prange-Kiel et al., 2003) and hippocampal slice cultures (Kretz et al., 2004). In addition, the maximum secreted E2 levels in hippocampal H19-7 cells were comparable to that report in hippocampal slice cultures (Kretz et al., 2004). Therefore, H19-7 hippocampal cells were a suitable model for studying the effect and mechanism of hippocampal E2 on hippocampal neuronal functions.

It has clearly been demonstrated that $\mathrm{GnRH}$ receptor expressed in hippocampus (Chu et al., 2008; Schang et al., 2011), thus, hippocampal neuron can selectively respond to $\mathrm{GnRH}$ treatment. In the present study, we reported the activating effect of GnRH on local hippocampal E2 level, indicating that $\mathrm{GnRH}$ enhanced endogenous E2 biosynthesis in hippocampal H19-7 cells. Similar to previous study, that demonstrated the activating 


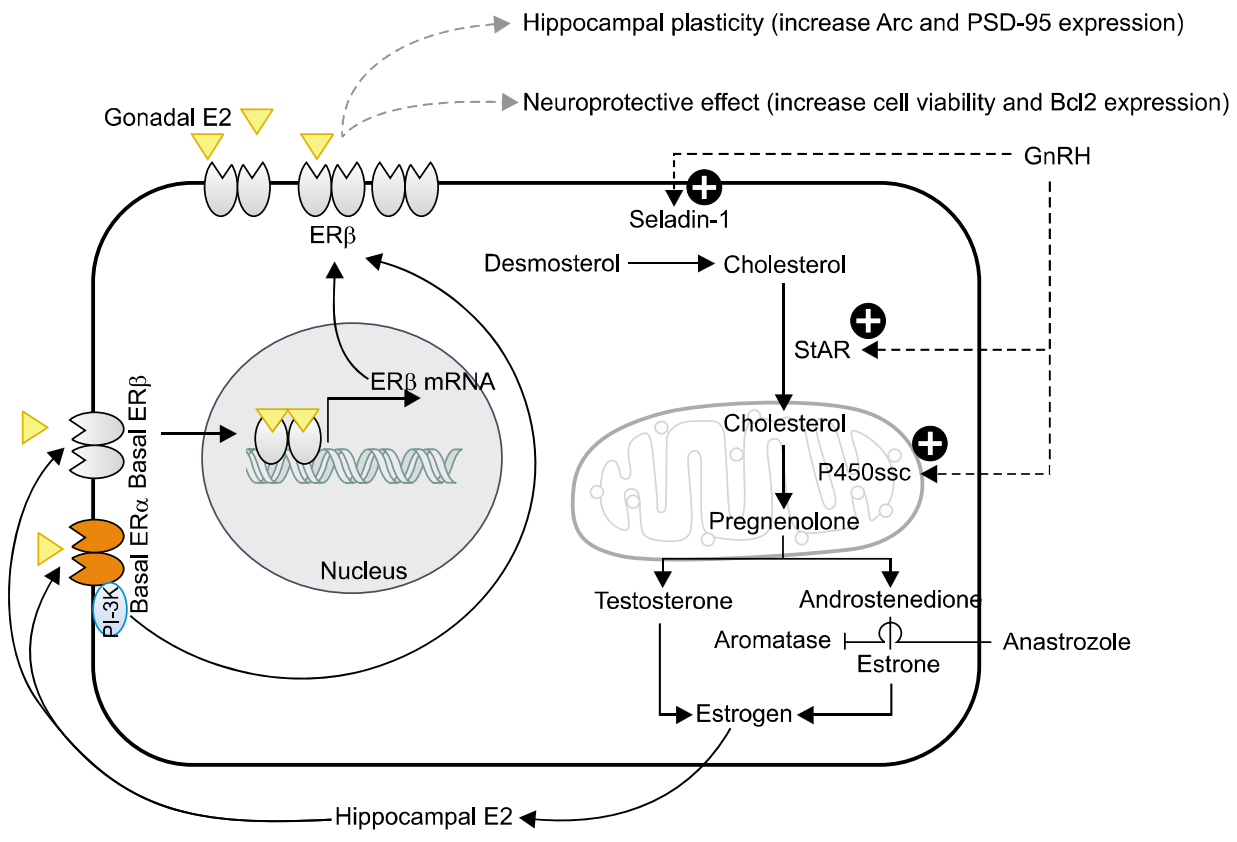

Figure 6. Schematic hypothetical model illustrating the prerequisite action of local hippocampal E2 on exogenous E2-induced synaptic plasticity and neuroprotection. GnRH enhanced local hippocampal E2 biosynthesis possibly via seladin-1, StAR, and P450scc expression. Hippocampal E2 biosynthesis regulates by endogenous aromatase activity. Secreted hippocampal E2 activates basal $E R \alpha$ and $\operatorname{ER} \beta$ to further upregulate $E R \beta$ expression. Hippocampal synaptic plasticity enhancing and neuroprotective functions of exogenous E2 mediates by ER $\beta$.

effect of $\mathrm{GnRH}$ on $\mathrm{E} 2$ biosynthesis and secretion in SH-SY5Y neurons (Rosati et al., 2011). GnRH enhanced the expression of enzymes involved in E2 biosynthesis, including seladin-1, steroidogenic acute regulatory protein (StAR), and cytochrome P450 (Attar and Bulun, 2006), indicated the feasibility of using hippocampal H19-7 cell for investigating the role of local E2 on hippocampal function.

There are two ER subtypes, ER $\alpha$ and ER $\beta$, which are expressed in hippocampus (Bliss and Collingridge, 1993). Expressions of those ERs are regulated by its ligand, E2 (Murata et al., 2003; Oliveira et al., 2004). In the present study, we showed the direct activating action of local hippocampal E2 on ER $\beta$ expression. Suppression of the local E2 by aromatase inhibitor led to downregulation of ER $\beta$ expression in hippocampal neurons. Local hippocampal E2 had no effect on $E R \alpha$ expression. In hippocampus, ER $\beta$ play an important role in long-term potentiation (LTP) enhancement, memory improvement (Day et al., 2005; Liu et al., 2008), and neuroprotection (Dubal et al., 1999; Zhao et al., 2004). The autocrine and paracrine actions of hippocampal E2 on an enhancement of ER $\beta$ expression are suggested to prime hippocampal neurons for further activation by exogenous E2.

We also demonstrated that hippocampal E2 acted through basal ER $\alpha$-PI-3K-dependent pathway to enhance ER $\beta$ expression, which classified as a non-genomic pathway. Membrane ER $\alpha$ directly interacted with PI-3K (Simoncini et al., 2003), therefore ER $\alpha$ agonist PPT failed to activate wortmannin-treated cells. On the other hand, local hippocampal E2 activated nuclear translocation of basal ER $\beta$ in H19-7 hippocampal cells, which was consistent with our previous report (Chamniansawat and Chongthammakun, 2010). Exogenous E2 activated ER $\beta$ translocation into nucleus to enhance synaptic plasticity (Chamniansawat and Chongthammakun, 2010), hence local hippocampal and exogenous E2 regulated neuronal function in classical genomic ER $\beta$-dependent mechanism.

Previously, the potential action of hippocampal and exogenous E2 on hippocampal synaptic plasticity has been reported (Gould et al., 1990; Prange-Kiel and Rune, 2006). Little is known about the interactive function of local hippocampal and exogenous E2 on synaptic plasticity. Exogenous E2 upregulated synaptic plasticity marker expression in hippocampal H19-7 cells. However, when endogenous E2 synthesis was inhibited by aromatase inhibitor anastrozole, exogenous E2 could not enhance synaptic plasticity in hippocampal H19-7 cells, suggesting that exogenous E2 function is endogenous E2-dependent mechanism. Previously, ER $\beta$ knockout mice exhibited attenuation of hippocampal plasticity and memory impairment (Day et al., 2005; Liu et al., 2008) although exogenous E2 is still present. Since the downregulation of ER $\beta$ expression is demonstrated in anastrozole-treated hippocampal H19-7 cells, E2 could not enhance hippocampal synaptic plasticity similar to those transgenic mice. The priming action of local hippocampal E2 on ER $\beta$ expression is suggested to 
be essential for exogenous E2-enhanced hippocampal synaptic plasticity.

Neuroprotective function of both exogenous E2 and endogenous E2 has been identified (Dubal et al., 1999; McCullough et al., 2003; Zhao et al., 2004). Exogenous E2 exclusively mediated Bcl2 expression, but not other Bcl2 family, including Bax, $\mathrm{Bcl}-\mathrm{xl}, \mathrm{Bcl}-\mathrm{xs}$, and Bad, to prevent neuronal death in ischemic brain injury model (Dubal et al., 1999). On the other hand, aromatase knockout mice exhibited higher brain damage than the wild type-OVX mice after cerebral artery occlusion (McCullough et al., 2003), indicated an important role of local E2 on neuronal viability. In the present study, we reported the priming action of hippocampal E2 on exogenous E2 enhanced hippocampal H19-7 cell viability and Bcl2 expression. Local hippocampal E2 influenced $E R \beta$ expression that required for exogenous E2-enhanced $\mathrm{Bc} / 2$ expression and neuronal viability (Dubal et al., 1999; Zhao et al., 2004). Therefore, neuroprotective action of exogenous E2 requires autocrine and paracrine actions of hippocampal E2-induced ER $\beta$ expression.

In conclusions, our study demonstrated the priming action of hippocampal E2 on systemic E2 functions, as depicted in Figure 6. Endogenous aromatase mediates H19-7 hippocampal E2 biosynthesis. GnRH enhances hippocampal E2 biosynthesis and secretion probably via StAR and P450scc activation (Mukai et al., 2010). Secreted hippocampal E2 upregulates hippocampal ER $\beta$ expression through basal ER $\alpha$ and ER $\beta$ activations. The basal ER $\alpha$ activation directly mediates $\mathrm{PI}-3 \mathrm{~K}$ signaling pathway, whereas basal ER $\beta$ activation translocates into nucleus. This mechanism provides the hippocampal ER $\beta$ to respond to systemic E2 lead to enhance hippocampal synaptic plasticity and neuroprotection.

\section{Methods}

\section{Cell culture}

H19-7 cells of hippocampal origin (H19-7 hippocampal cells; ATCC ${ }^{R}$ Number, CRL-2526 ${ }^{\mathrm{TM}}$ ) were grown on poly-L-lysine-coated dishes, in Dubecco's modified Eagle's medium (DMEM; Gibco-BRL, Grand Island, NY) in a $5 \% \mathrm{CO}_{2}$ humidified atmosphere at $33^{\circ} \mathrm{C}$ as described previously (Bhargava et al., 2000). Hippocampal H19-7 cells are transformed with a temperature-sensitive mutant of simian virus $40 \mathrm{~T}$ antigen and are conditionally differentiated. For differentiation, cells were incubated in a $5 \% \mathrm{CO}_{2}$ humidified atmosphere at $39^{\circ} \mathrm{C}$ in DMEM and $\mathrm{N}_{2}$ supplements (Invitrogen, Carlsbad, CA), and the process was accelerated by adding $10 \mathrm{ng} / \mathrm{ml}$ basic fibroblast growth factor (Sigma, St. Louis, MO). To find out the optimal level of E2 secretion, hippocampal H19-7 cells were incubated with culture media, $25 \mathrm{nM}$ anastrozole-containing culture, or $0.01 \mu \mathrm{M}$ GnRH-containing culture media for 12 days. To investigate the effect and mechanisms of local hippocampal E2 on exogenous E2, cells were treated with $10 \mathrm{nM} \mathrm{E2,} 25$ $\mathrm{nM}$ anastrozole, $100 \mathrm{nM}$ PPT, $100 \mathrm{nM}$ DPN, or $200 \mathrm{nM}$ wortmannin according to the need of each experiment. All stimulant drugs are purchased from Sigma.

\section{ELISA}

To evaluate secreted E2 levels in culture media, colorimetric rat E2 ELISA kits (TSZ ELISA; Framingham, MA) was performed according to the manufacturer's instructions. Briefly, culture medium were pipetted into micro-assay well which had been precoated with monoclonal antibody against E2, followed by incubation at $37^{\circ} \mathrm{C}$ for $30 \mathrm{~min}$. And then washing buffer was added to wash an excess binding before added HRP-conjugated reagent to each well. To develop the reaction, chromogen substrate was added and incubated at $37^{\circ} \mathrm{C}$ for $15 \mathrm{~min}$ in light protection. The reaction were stopped by add $50 \mathrm{ml}$ stop solution into each well. Absorbance was read at $540 \mathrm{~nm}$ on a microplate reader (Bio-Tek). Samples were quantified by interpolation with standard curve.

\section{Immunocytochemistry}

For immunocytochemistry, hippocampal H19-7 cells were seeded on 12-mm glass coverslips at a density of 10,000 cells/coverslip and cultured overnight as previously described (Chamniansawat and Chongthammakun, 2009). At the end of all treatments, cells were fixed for $15 \mathrm{~min}$ in $4 \%$ paraformaldehyde at $4^{\circ} \mathrm{C}$, followed by permeabilization in $0.2 \mathrm{M}$ glycine. After blocking of nonspecific binding, cells were incubated overnight at $4^{\circ} \mathrm{C}$ with $1: 100$ mouse anti-ER $\alpha$ or 1-100 mouse anti-ER $\beta$ antibodies (Abcam, Cambridge, UK). After washing away excess primary antibodies, cells were then incubated with 1:1000 fluorescien isothiocyanate (FITC)-coupled anti-mouse IgG secondary antibody (Zymed), and subsequently stained for nuclei with 1:500 TROPO-3 (Molecular Probes, Eugene, OR). We used a confocal laser-scanning microscope (model FV 1000; Olympus, Tokyo, Japan) to analyze the fluorescent signals.

\section{Western blot analysis}

Western blot analysis was performed as described previously (Chamniansawat and Chongthammakun, 2009). H19-7 hippocampal cells were lysed with RIPA buffer. Equal amounts of protein were separated on $10 \%$ SDS-PAGE, and transferred onto nitrocellulose membranes. The membranes were incubated with 1:1000 mouse anti-ER $\alpha,-E R \beta$, -Arc (Santa Cruz Biotechnology Inc., Santa Cruz, CA), rabbit anti-PSD-95 (Abcam), or -Bcl2 (Abcam) antibodies, and then incubated with a HRP-conjugated secondary antibody (Zymed, San Francisco, CA). The signal was detected with ECL Western blotting substrate (Pierce, Rockford, IL) and captured on Hyperfilm ${ }^{\mathrm{TM}}$ (Amersham Pharmacia Biotech, Piscataway, NJ). 


\section{Quantitative real time-PCR (qRT-PCR)}

To determine mRNA levels of Arc, PSD-95, ER $\alpha, E R \beta$, and $B c / 2$ in H19-7 hippocampal neuron, total RNA was extracted by using the RNeasy Mini kit (Qiagen, Hilden, Germany) following the manufacturer's protocol as previously described (Chamniansawat and Chongthammakun, 2009). A $2 \mu \mathrm{g}$ total RNA was converted to cDNA with the high capacity cDNA reverse transcription kit (Applied Biosystems, Foster City, CA). Quantitative real-time PCR (qRT-PCR) was performed on the Applied Biosystems PRISM 7700 Sequence Detection System using TaqMan-Gene Expression Assays with FAM $^{\mathrm{TM}}$ dye-labeled TaqMan ${ }^{\circledR}$ MGB probes, which contained customized primer design according to the manufacturer's protocol. The positive endogenous control was GAPDH and the negative control was water. The relative expression of mRNA was calculated using the comparative Ct method by using SDS software v.1.3.1 (Applied Biosystems). All data were normalized with the endogenous reference gene GAPDH expression (Applied Biosystems).

\section{MTT reduction assay}

The cell viability was determined by the quantitative colorimetric with MTT assay (3-(4,5-dimethylthiazole-2-yl)-2, 5-diphenyltetrazolium bromide, Sigma). Cells were plated on 96-well culture plates at a density of 10,000 cells per well. Cells were cultured in media or media containing anastrozole for 8 days, then, treated with $200 \mu \mathrm{M}$ hydrogen peroxide $\left(\mathrm{H}_{2} \mathrm{O}_{2}\right)$ or culture media for $1 \mathrm{~h}$. The medium was removed and mixed with a solution of $1 \mathrm{mg} / \mathrm{ml}$ MTT for $3 \mathrm{~h}$ in a $5 \% \mathrm{CO}_{2}$ humidified atmosphere at $37^{\circ} \mathrm{C}$. The supernatant was then removed, and the formazan crystals in the cells were solubilized with DMSO. Absorbance was read at $570 \mathrm{~nm}$ on a microplate reader.

\section{Data analysis}

All data were expressed as mean \pm SEM. Two sets of data were compared using the unpaired Student's $t$-test. One-way analysis of variance (ANOVA) with Tukey's posttest was employed for multiple sets of data. The level of significance of all statistical tests was $P<0.05$. Linear regression and non-linear regression analysis were performed to obtain the \% maximum secreted E2-incubation period relationship. All data were analyzed by GraphPad Prism version 5.0 for Window (GraphPad Software Inc., San Diego, CA).

\section{Acknowledgements}

This work was supported by grants from the Thailand Research Fund and Higher Education Commission (No. MRG5480211) and Higher Education Commission (No. $44496)$ to S. Chamniansawat. We also thanks Dr. Narongrit Thongon for a kind technical assistance.

\section{References}

Attar E, Bulun SE. Aromatase and other steroidogenic genes in endometriosis: translational aspects. Hum Reprod Update 2006;12:49-56

Bhargava A, Meijer OC, Dallman MF, Pearce D. Plasma membrane calcium pump isoform 1 gene expression is repressed by corticosterone and stress in rat hippocampus. J Neurosci 2000;20:3129-38

Bliss TV, Collingridge GL. A synaptic model of memory: long-term potentiation in the hippocampus. Nature 1993; $361: 31-9$

Chamniansawat $\mathrm{S}$, Chongthammakun S. Estrogen stimulates activity-regulated cytoskeleton associated protein (Arc) expression via the MAPK- and PI-3K-dependent pathways in SH-SY5Y cells. Neurosci Lett 2009;452:130-5

Chamniansawat S, Chongthammakun S. Genomic and non-genomic actions of estrogen on synaptic plasticity in SH-SY5Y cells. Neurosci Lett 2010;470:49-54

Chu C, Gao G, Huang W. A study on co-localization of FSH and its receptor in rat hippocampus. J Mol Histol 2008;39: 49-55

Day M, Sung A, Logue S, Bowlby M, Arias R. Beta estrogen receptor knockout (BERKO) mice present attenuated hippocampal CA1 long-term potentiation and related memory deficits in contextual fear conditioning. Behav Brain Res 2005;164:128-31

Dubal DB, Shughrue PJ, Wilson ME, Merchenthaler I, Wise PM. Estradiol modulates $\mathrm{Bcl} 2$ in cerebral ischemia: a potential role for estrogen receptors. J Neurosci 1999;19: 6385-93

Gorenstein C, Rennó J, Vieira Filho AH, Gianfaldoni A, Gonçalves MA, Halbe HW, Fernandes CE, Demétrio FN. Estrogen replacement therapy and cognitive functions in healthy postmenopausal women: a randomized trial. Arch Womens Ment Health 2011;14:367-73

Gould E, Woolley CS, Frankfurt M, McEwen BS. Gonadal steroids regulate dendritic spine density in hippocampal pyramidal cells in adulthood. J Neurosci 1990;10:1286-91

Henderson VW. Action of estrogens in the aging brain: dementia and cognitive aging. Biochim Biophys Acta 2010; 1800:1077-83

Hojo Y, Hattori TA, Enami T, Furukawa A, Suzuki K, Ishii HT, Mukai H, Morrison JH, Janssen WG, Kominami S, Harada $\mathrm{N}$, Kimoto T, Kawato S. Adult male rat hippocampus synthesizes estradiol from pregnenolone by cytochromes P45017alpha and P450 aromatase localized in neurons. Proc Natl Acad Sci USA 2004;101:865-70

Kretz O, Fester L, Wehrenberg U, Zhou L, Brauckmann S, Zhao S, Prange-Kiel J, Naumann T, Jarry H, Frotscher M, Rune GM. Hippocampal synapses depend on hippocampal estrogen synthesis. J Neurosci 2004;24:5913-21

Liu F, Day M, Muñiz LC, Bitran D, Arias R, Revilla-Sanchez R, Grauer S, Zhang G, Kelley C, Pulito V, Sung A, Mervis RF, Navarra R, Hirst WD, Reinhart PH, Marquis KL, Moss SJ, Pangalos MN, Brandon NJ. Activation of estrogen receptor- 
beta regulates hippocampal synaptic plasticity and improves memory. Nat Neurosci 2008;11:334-43

McCullough LD, Blizzard K, Simpson ER, Oz OK, Hurn PD. Aromatase cytochrome P450 and extragonadal estrogen play a role in ischemic neuroprotection. J Neurosci 2003;23: 8701-5

Murata T, Narita K, Honda K, Matsukawa S, Higuchi T. Differential regulation of estrogen receptor alpha and beta mRNAs in the rat uterus during pregnancy and labor: possible involvement of estrogen receptors in oxytocin receptor regulation. Endocr J 2003;50:579-87

Mukai H, Kimoto T, Hojo Y, Kawato S, Murakami G, Higo S, Hatanaka Y, Ogiue-lkeda M. Modulation of synaptic plasticity by brain estrogen in the hippocampus. Biochim Biophys Acta 2010;1800:1030-44

Oliveira CA, Mahecha GA, Carnes K, Prins GS, Saunders PT, França LR, Hess RA. Differential hormonal regulation of estrogen receptors ERalpha and ERbeta and androgen receptor expression in rat efferent ductules. Reproduction 2004;128:73-86

Prange-Kiel J, Rune GM. Direct and indirect effects of estrogen on rat hippocampus. Neuroscience 2006;138: 765-72

Prange-Kiel J, Wehrenberg U, Jarry H, Rune GM. Para/ autocrine regulation of estrogen receptors in hippocampal neurons. Hippocampus 2003;13:226-34

Rosati F, Sturli N, Cungi MC, Morello M, Villanelli F, Bartolucci
G, Finocchi C, Peri A, Serio M, Danza G. Gonadotropinreleasing hormone modulates cholesterol synthesis and steroidogenesis in SH-SY5Y cells. J Steroid Biochem Mol Biol 2011;124:77-83

Schang AL, Ngô-Muller V, Bleux C, Granger A, Chenut MC, Loudes C, Magre S, Counis R, Cohen-Tannoudji J, Laverrière $\mathrm{JN}$. GnRH receptor gene expression in the developing rat hippocampus: transcriptional regulation and potential roles in neuronal plasticity. Endocrinology 2011; 152:568-80

Simoncini T, Rabkin E, Liao JK. Molecular basis of cell membrane estrogen receptor interaction with phosphatidylinositol 3-kinase in endothelial cells. Arterioscler Thromb Vasc Biol 2003;23:198-203

Woolley CS, McEwen BS. Estradiol mediates fluctuation in hippocampal synapse density during the estrous cycle in the adult rat. J Neurosci 1992;12:2549-54

Zhao L, Wu TW, Brinton RD. Estrogen receptor subtypes alpha and beta contribute to neuroprotection and increased $\mathrm{Bcl} 2$ expression in primary hippocampal neurons. Brain Res 2004;1010:22-34

Zhou L, Fester L, von Blittersdorff B, Hassu B, Nogens H, Prange-Kiel J, Jarry $\mathrm{H}$, Wegscheider K, Rune GM. Aromatase inhibitors induce spine synapse loss in the hippocampus of OVX mice. Endocrinology 2010;151: 1153-60 